\title{
The valley of the fallen: a new El Escorial for Spain
}

\section{Queralt Solé Universitat de Barcelona}

queraltsole@ub.edu

\begin{abstract}
Since the beginning of the twenty-first century, Spain has experienced a cycle of exhumations of the mass graves of the Spanish Civil War (1936-39) and has rediscovered that the largest mass grave of the state is the monument that glorifies the Franco regime: the Valley of the Fallen. Building work in the Sierra de Guadarrama, near Madrid, was begun in 1940 and was not completed until 1958. This article analyses for the first time the regime's wish, from the start of the works, for the construction of the Valley of the Fallen to outdo the monument of El Escorial. At the same time the regime sought to create a new location to sanctify the dictatorship through the vast transfer to its crypts of the remains of the dead of the opposing sides of the war.
\end{abstract}

Key words: Valley of the Fallen, historical memory, Francoism, Spanish Civil War, human remains, mass graves

\section{Introduction}

In 1940 a decree was published ordering the construction of a large monument that would feature a universally recognised Christian basilica and be set in the Sierra del Guadarrama, to the north Madrid. The location, called Cuelgamuros, was to be transformed into an eternal memorial for those who had sacrificed their lives for Spain - all of whom would be from the winning side of the Spanish Civil War (1936-39). It was to be built within a year. The work in fact took eighteen years and the monument was not officially inaugurated until 1959. Since it was to be a place of commemoration and honour, it was originally conceived and designed to house the mortal remains of the Francoist soldiers who had fallen at the front or of civilians and priests murdered in the Republic's rear. The fact that the construction of the Valley of the Fallen became so drawn out over time meant that in the end, and starting in 1958, human remains from both sides of the civil war were brought from all over Spain - the bones of Francoist soldiers and those of Republican soldiers - usually without their families being informed of the final resting place of their loved ones' remains. The last interment in the Valley of the Fallen was 
in 1983 - that is, after democracy had been re-established. Since then, the crypts housing the remains of thousands of people who died during the war have not been reopened except on a few rare occasions such as for one-off exhumations or assessments of the state of preservation of the remains.

This work presents a short account of historical studies centred on the monument and, based on previously established historical information, briefly explains the history of the Valley of the Fallen and the transfer into its crypts of the remains of those who died in the civil war. It argues that the wish of the Francoist regime was to outdo the royal pantheon of San Lorenzo de El Escorial in terms of both size and significance. As will be seen, the monument constructed at Paracuellos has been the subject of historiographical and sociological analysis, but to date it has not been empirically compared with the monument of El Escorial. For the purposes of this comparison and to lend support to the theory regarding Franco's wish to erect a new monument greater El Escorial and for a new dynasty, the following sources have been used: documentation produced by the Council of Works of the Monument to the Fallen, which is preserved in the General Archives of the Administration (in Alcalá de Henares); documentation from the Provincial Archives of Lérida; and municipal documentation preserved by various local councils in the province of Tarragona. News and articles published in various newspapers of the time - in particular La Vanguardia Española, and also La Hoja del Lunes and Imperio: Diario de Zamora - were also located and analysed. They are not without political bias, as these were newspapers from the end of the regime. But it is precisely this bias that allows us to see the message and ideas that the dictatorship was hoping to convey to society in regard to the monument of the Valley of the Fallen. Although this type of press is a biased primary source, the bias allows us to analyse Franco's wish to create in the imagination of the Spanish citizen first the construction and then the existence of a great and enduring monument that must be superior to the royal pantheon of San Lorenzo de El Escorial.

\section{A permanent memorial to the civil war}

The Spanish Civil War officially ended on 1 April 1939. It had begun because of the failure of the military coup of 18 July 1936 initiated by various army factions that wanted to overthrow the Republican regime established in 1931. For almost three years the rebel troops fought the Republic until it was defeated. The war ended, but peace never came. ${ }^{1}$ Instead, a harsh dictatorship began that lasted until the death of Francisco Franco on 20 November 1975, and for almost forty years the Francoist regime used the memory of the civil war as a means of creating fear, repression as an instrument of terror and accentuation of the difference between victors and vanquished as a key and central instrument. It did so because it divided society into good and bad. And against the possibility of a better and righteous future it placed a past and present comprised only of survival and corruption. The backbone of the Francoist regime, once the terror of the war and the first few post-war years were over, was the constant reminder of the fact that some had won the war and others had been not only beaten but totally defeated. 
Once the war was over the regime used various ways of differentiating between the two sides and it tried to ensure that difference was replicated in every area and aspect of people's lives. It is not necessary here to emphasise the matter of repression, by which denouncing or vouching for people who were considered to be 'fanatics' could end or save the lives of men and women. In addition to the physical repression resulting in death or deprivation of liberty, for many years finding work depended on one's own background and that of one's family. Civil service posts were occupied by the victors or their close friends and family. Access to state assistance for those wounded or maimed in the war, as well as for those widowed, depended on whether or not they were considered loyal to the 'Movement'. Even the dead were charged differently in terms of burials, graves and taxes, based on whether or not the dead person was a 'supporter of the Movement'. Attempts were made to cover every aspect of professional, cultural, daily and leisure life in which this division could be emphasised and made evident. There was also a desire to transform the landscape by covering it with monuments. Artificial elements were continually imposed on the environment by erecting a wide variety of monuments across the whole of Spain from 1939 onwards to commemorate the dictator and his victory. ${ }^{2}$

Spaniards' everyday landscape was full of new elements that attempted to make permanent the memory of the war and of Franco's victory: the Arco de Triunfo in Madrid; the monument to Onésimo Redondo ${ }^{3}$ on the Hill of San Cristóbal (Valladolid) and the monument erected to General Emilio Mola ${ }^{4}$ near Alcocero (Burgos); monuments commemorating battles, such as that erected in the ruined town of Belchite (Zaragoza) or the one in Bot to remember the Battle of the Ebro (Tarragona); statues of Franco in the big cities; solitary crosses on roadsides and in various locations to commemorate the dead of Franco's army in an individual way; plaques in churches throughout the country in memory of those 'Fallen for God and for Spain', a reference to soldiers who had died at the front or had been killed in reprisals in the Republican rear (the so-called martyrs); and crypts and monuments in cemeteries that paid homage to the fallen of the war. And what encompassed within itself the constant memory of this victory, reiterating the Catholic Church's support for the victors and the regime in and perpetuating the memory of the war through the remains of the dead held within it, leaving no room for any doubt regarding its ambition to endure, was and is the Valley of the Fallen, in the valley of Cuelgamuros, some fifty kilometres from Madrid, on a plot occupying 1,377 hectares of the municipality of San Lorenzo de El Escorial.

\section{A limited historiography}

The current historiography focuses little on the Valley of the Fallen. The first reference book on the monument at Cuelgamuros was written by a journalist and for decades was the only book on the Valley of the Fallen. Daniel Sueiro published $E l$ Valle de los Caidos: Los secretos de la cripta franquista (The Valley of the Fallen: The Secrets of the Francoist Crypt) in 1977 and the work was republished in 1983 and $2006 .{ }^{5}$ It is a very well-documented study, especially when one considers 
the period when his investigation took place. He had no opportunity to consult archival sources, as either he was unable to locate them or they had not yet been made public. Despite this, in terms of its information on the history of the monument - who built the Valley of the Fallen and how, figures on construction costs, witness statements, details on escaped prisoners, analysis of the works of sculpture on show, interviews that were conducted - and its very generally focused research findings, it does not differ much from what Olmeda offers in the other book of research focused on the Valley of the Fallen, which was published in 2009. El Valle de los Caídos: Una memoria de España (The Valley of the Fallen: A Memory of Spain $)^{6}$ was also written by a journalist, and throughout the work he explains how the idea for the monument developed, as well as who built it and under what circumstances. He collects various witness statements, analyses the accounts to which he had access and even approaches the parliamentary discussions on the subject in the first decade of the twenty-first century. When they were published both books stood in contrast to others of an opposing ideological stance. In 1976 the Francisco Franco Foundation published an essay ${ }^{7}$ that was intended to counteract Daniel Sueiro's work; and in 2009 a book by Juan Blancowas published that was intended to counteract that of Olmeda. ${ }^{8}$

As stated above, on a historiographical level there have been very few historical studies. Among them, it is worth highlighting those of Queralt Solé, ${ }^{9}$ who located the documentation relating to the transfer of remains to the Valley of the Fallen from all over Spain and focused on the opening of mass graves and the transfer of the exhumed human remains - especially those from Catalonia - to the crypts of the Valley of the Fallen from 1958 onwards. Focusing his analysis on the same issue, José Díaz Arriaza (2011) has published work on the transfer of remains from Seville's cemetery. Another study that is worth mentioning is that by Alberto Bárcena, ${ }^{10}$ who conducted an in-depth investigation of the documentation held in the General Archives of the Royal Palace of Madrid (sixty-nine boxes) to analyse the system of 'Sentence Reduction through Work' and the circumstances of the prisoners who worked on the construction of the monument. His study counterbalances what he himself calls the 'black legend' of the Valley of the Fallen, according to which the prisoners were poorly treated, undernourished and suffered a very high death rate. It is a pity that, having uncovered this reality of the construction work -which appears to demonstrate that the situation of these prisoners was privileged in comparison to that of others- Bárcena extrapolates his interpretation more generally and argues that the monument itself and the inauguration of the Valley of the Fallen signified and achieved a true national reconciliation. The fact that a 'black legend' has grown up over the years around certain aspects of the monument does not mean that it is not of great political significance, as is indeed evident.

Although from a historiographical point of view the Valley of the Fallen has not become a central focus of analytical study, and although certain aspects of this subject still remain to be understood, ${ }^{11}$ much more work has been done on its memorial aspects. Understandably, the Valley of the Fallen is positioned as an example - and indeed it is one - of the imposition of a single memory of the past. 
Among such studies it is worth noting the analyses carried out by Josefina Cuesta, ${ }^{12}$ Zira Box ${ }^{13}$ and, above all, Paloma Aguilar. ${ }^{14}$ The latter, a political scientist, was one of the first to approach the monument from the perspective of its importance as the disseminator of an unequivocal message through which - despite the belated attempt of the dictatorship (although not of Franco) to change its significance and transform it, on its inauguration, into a monument of reconciliation - 'the official memory could not be imposed onto the consciousness of the majority, and the Valley of the Fallen is remembered as an ostentatious and unfortunate pantheon that Franco made for himself and for the victors of the war'. ${ }^{15}$ The political scientist Katherine Hite also analyses the Valley of the Fallen, comparing it to monuments and memorials in South America. ${ }^{16}$ She concludes that 'in this way, inasmuch as it is an obsessive symbolic legacy, Franco's Valley of the Fallen represents the ultimate incarnation of the alliance between the army, the Church and the Right, together with the primacy of Spain as defender of Western civilisation' ${ }^{17}$

The Valley of the Fallen has been analysed by various people as paradigmatic of a partisan memory of the war and the dictatorship. Among the works written from this perspective, the contributions by Luis Castro, ${ }^{18}$ Marlène Albert-Llorca ${ }^{19}$ and Francisco Ferrándiz ${ }^{20}$ - the latter two are anthropologists - stand out. In his analysis, Ferrándiz attaches great current importance to the monument as a subject that has acquired particular prominence in the debate around how to read and act today in respect of the memory of the civil war and the dictatorship. Such are the possibilities for the study, analysis and interpretation of the Valley of the Fallen that the archaeologist Alfredo González Ruibal has published an analysis of the remains from the point of view of his specialism. ${ }^{21}$ In this work, he proposes a dual strategy for the ideological deconstruction of the Valley of the Fallen, carrying out archaeological excavations on the site that are focused, above all, on analysing the conditions in which the prisoners worked, based on remnants which have resisted the passage of time and on separating and differentiating the Francoist monument from the other monuments now managed by National Heritage. This is done in order to add it to tourist itineraries of the surviving remains of the civil war, such as trenches, shelters, front lines and so forth, thereby situating it as another vestige of the combat.

Beyond academic works, in this era of visual culture in which we live we should mention the various audiovisual productions focused on the Valley of the Fallen that have been made. In these, direct witnesses and historians are interviewed; the search for and locating of documentation is portrayed; and historical and current images are shown. As well as the news of that time, which can be seen on the internet via a channel on NO-DO, ${ }^{22}$ the official news channel of the Francoist regime, in 2006 the documentary La memoria es vaga (Memory is Vague) was produced, while in 2009 two reports based on the Valley of the Fallen were broadcast on Antena3 Televisión (a private state channel). These were entitled Franco, Operación Caídos (Franco, Operation Fallen) and El Valle de los Caídos, la obsesión de Franco (The Valley of the Fallen, Franco's Obsession). In 2012, Alessandro Pugno produced the film A la sombra de la cruz (In the Shadow of the Cross), which claimed to be a neutral vision - there is no narrator in the film - of the daily life of the Benedictine 
community that resides in the Valley of the Fallen and of the education received by the children who go to school there. Despite no opinion whatsoever being uttered, it is still shocking to see how both the community and the children who attend the school live alongside a monument (as well as sculptures, furnishings and a landscape) that is so markedly ideological. One could make a very suggestive analysis, although there is no room to do so here, of the scene in which the children file past Franco's tomb to take communion. It is evidence of a daily coexistence with death and the dead person - a dictator - at moments of religious significance such as the taking of communion. In 2013 the last film of those made to date was broadcast, in this instance by a regional public television channel (TV3, in Catalonia). It is entitled Te sacaré de aquí, abuelo! (I'll Get You Out of Here, Grandad!), and it reveals the condition and location of the human remains in the crypts and the hopes expressed by various family members that they will be exhumed. As Moreno and Rueda $^{23}$ point out, all these films - except for the one by Pugno - imbue the area of the Valley of the Fallen with a feeling of violence and arrogation with regard to those who lost the war and their families. ${ }^{24}$

Before we end this brief overview of historiographical writings and productions on the Valley of the Fallen, it is necessary to point out that, due to the debate that has existed in Spain since the year 2000 regarding Francoist memory and democratic memory, as well as due to the respective public policies that have been created or for which there is a demand, there have been more writings on the Valley of the Fallen by Spanish political or legal institutions, which have been followed by references in the press because of the interest to which they give rise, than there have been writings produced by the academic world. Likewise, the whole body of documentation generated during the democratic era has not yet been subjected to analysis, except for the above-mentioned anthropological study by Ferrándiz. ${ }^{25}$

\section{The biggest mass grave in Spain}

Just one year after the end of the war, on 1 April 1940, a decree from the president of the government was passed. It was published in the official state bulletin on 2 April: 'Decree of 1 April 1940 providing for the erection of a basilica, monastery and youth centre on the land situated on the slopes of the Sierra de Guadarrama (El Escorial), known as Cuelgamuros, to preserve the memory of those who fell in our Glorious Crusade. ${ }^{26}$ The preamble of the decree set out very clearly the objective of the construction and the reason for undertaking a work that would stand the test of time, be different from the lesser monuments that were being erected in towns and villages and last forever,: 'The stones erected must be of the size of those of the monuments of antiquity, defy time and oblivion, and create a place of meditation and rest where future generations may pay a homage of admiration to those who bequeathed them a better Spain. ${ }^{27}$ The declaration of intentions was also very clear about the ultimate objective: over time the monuments in squares - plaques, statues and so forth - could disappear. What was needed was something immovable and indestructible; it had to be a large, hugely ambitious monument; and for this reason it was designed to reach into the entrails of the earth. In the end, the 
basilica was excavated out of the rock in a place called Risco de la Nava, 'making it into a construction that is permanent and eternal and that rests in the earth, at the same time as rising above it'. ${ }^{28}$

Around this construction, which is topped by a cross almost 150 metres high, was built the monastery for the Benedictine monks (on the western side), together with the library and a study centre. On the south side, a large, flat area leading into the church precinct was created. A large lake in the shape of a cross was also planned, but ultimately could not be built. However, what was built was a funicular railway to take people from the flat area up to the base of the cross. The end result was a complex that, beyond the various interpretations that can be made of it, is spectacular, exactly as was hoped. The nave of the basilica is only slightly smaller than that of Saint Peter's Basilica (262 metres long and 18 metres wide). Enormous bronze sculptures (apparently cast from cannons used in the civil war) and stone were placed inside it, and in the six side chapels there are various representations of the Virgin Mary in different manifestations associated with the history of Spain, each of being a patron saint of a section or group of the Spanish armed forces. ${ }^{29}$ Various large sculptures are located in the transept and at the altar. In front of and behind the altar are buried José Antonio Primo de Rivera and Francisco Franco, and over their tombs there is a large cupola with a mosaic representing typical religious images. 'Beside the group of the Assumption of the Virgin', meanwhile, 'are the fallen civilians and clerics and the fallen soldiers of the War of 1936-39' ${ }^{30}$ In the cupola there are representations of Saint Teresa of Jesus, who became Franco's favourite saint. ${ }^{31}$ The result is a spectacular monumental and religious whole, where one constantly feels and breathes the memory not of civil war, but of the Francoist victory in the Spanish Civil War.

Originally, as I have explained, the aim was to complete the monument within one year and to place within it the remains of the Francoist soldiers who had been interred in temporary cemeteries all over the state or those of martyrs assassinated in the Republican rear. Great respect was expected and anticipated. The plan was announced in the official bulletins of the provinces and in the newspapers. It was not considered necessary to ask permission from the families of the Francoist soldiers to transfer their remains, unless they had specifically asked for them not to be transferred or for them to be taken somewhere other than Cuelgamuros. The crypts in the aisles of the basilica and in the sides of the transept were planned and built. When the monument was finally inaugurated in 1959, twenty years had passed since the end of the civil war. By that time the enthusiasm that might have existed in 1940 for families to request or agree that the remains of their loved ones be exhumed and transferred for interment in the great monument to victory had melted away. There were even communities that opposed any movement of remains; most significantly, the Carlists refused to allow their dead to be moved to the crypts of Cuelgamuros. ${ }^{32}$ There was also fierce opposition from the Association of the Families of Martyrs of Paracuellos to their dead being moved. ${ }^{33}$ In addition to the opposition and refusals was the fact that all over Spain, when local councils were asked for information about the existence of civil war mass graves, whether within or outside of their municipal cemeteries, they often replied that within the 
municipal boundaries there were burials of Republican ('Rojos' or 'red') soldiers: 'As this area was a front in the war, there are various individual and collective burial sites of soldiers of the red army, unidentified and of unknown numbers, some of which are now difficult to locate. ${ }^{34}$ It has yet to be confirmed whether or not the Catholic Church influenced the regime in 1959 to agree to interring the remains of the dead from both sides of the struggle, in order to obtain the Vatican's consent for the church's designation as a basilica, which took place in $1960 .{ }^{35}$

Whatever the case, quite aside from any explicit requests for, offers of or opposition to the transfer of remains, the regime wanted to fill the crypts with the remains of the dead of the civil war period - initially only those of the victors, but later those of both sides. To this end, it created a specific commission within the Council of Works of the Monument to the Fallen, which had been in operation since $1941 .^{36}$ The aim of the commission was to collect all information relating to the existing burial places of victims of the civil war and to manage their transfer to the Valley of the Fallen so that on the day of its inauguration the crypts would contain remains representative of the whole state.

Therefore in 1958, and in an international context that was very different from that of 1940, the regime contacted each and every Spanish local council through the Ministry of Administration for information on individual or communal burials that had occurred during the civil war and that were located within their municipal boundaries. In the notices that were sent out it was clearly specified that the bodies could belong to either side of the conflict and could be those of civilians or soldiers. The first of the notices was very clear on this matter:

One of the main aims that determined the construction of the National Monument to the Fallen in the Valley of Cuelgamuros (Guadarrama) was to provide a place of interment for those who were sacrificed for God and for Spain and for all those who fell in our Crusade, without distinction of the side on which they fought, as required by the Christian spirit that inspired this major work, so that it should be Spanish in nationality and Catholic in religion. ${ }^{37}$

Once the commission had collected all the required information it decided which human remains would be transferred and issued appropriate orders for this to be done. ${ }^{38}$ This included providing specifications for the wooden caskets that would contain the remains - the type of wood, the measurements and even the black paint with which they were to be painted.

At the same time an announcement was published in the provincial bulletins to the effect that those families of martyrs to the war who so wished could also take charge of the transfer of remains from their respective municipalities. There were few requests from these families; as has been mentioned, there was even some opposition to certain transfers being made. However, the remains that began to be transferred, primarily in army lorries from all over the state, were those of Francoist soldiers that had until then been in temporary military cemeteries and of Republican soldiers that had been interred in mass graves. The former were identified (if not individualised), because when they had been interred during the civil 

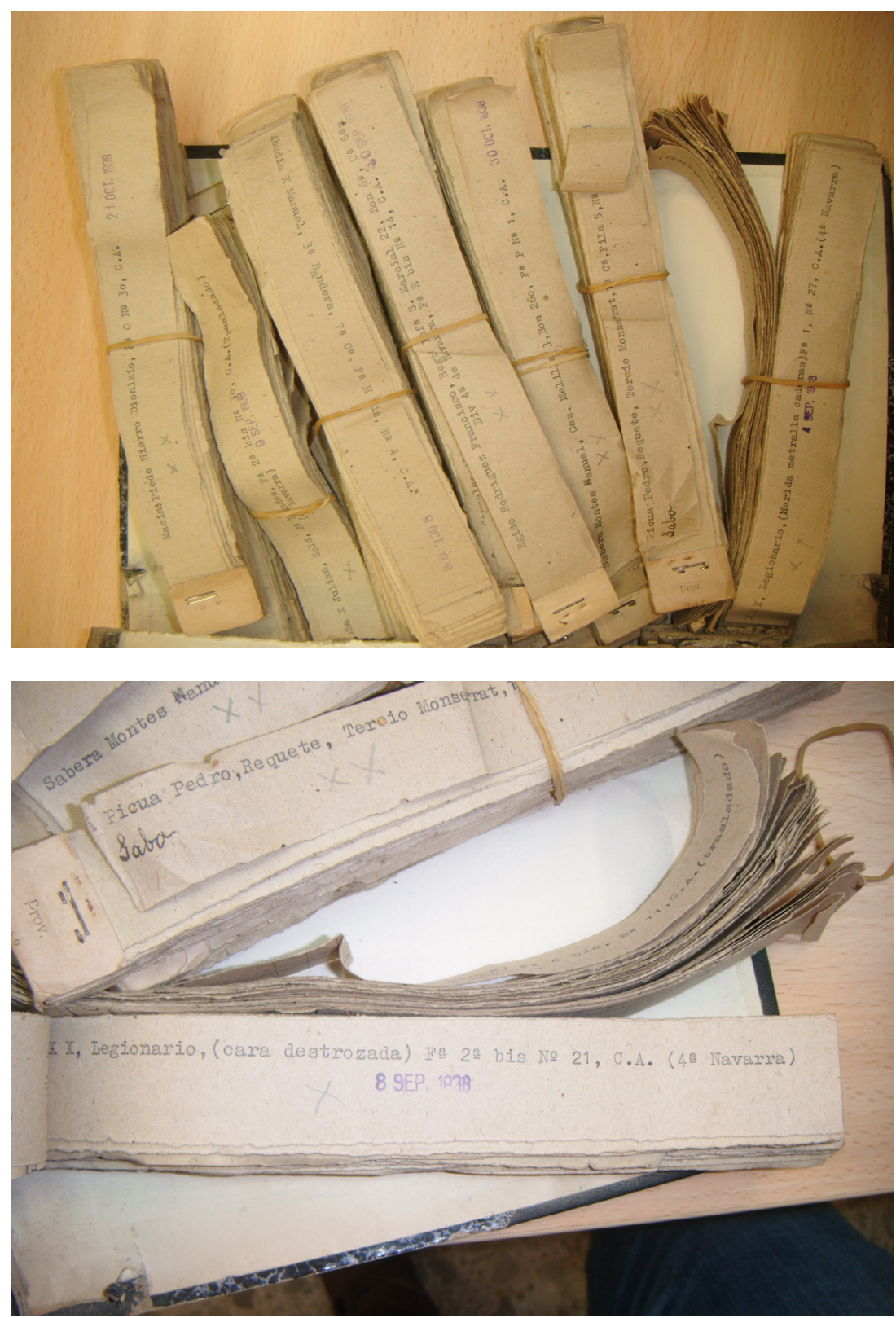

Figures 1 and 2 Documentation that was in the glass bottles of the Francoist soldiers buried in the cemetery of Batea (Tarragona). Detail of one of the identification documents, on which is written: 'X.X. Legionnaire (face destroyed) Fo 2nd bis No 21 C.A.(4th Navarra).' Municipal Archives of Batea (Tarragona). 


\section{Queralt Solé}

war the rebels' order of January 1937 had been followed that specified that fallen soldiers should be buried with a glass bottle containing their identity papers by their head or feet (figures 1 and 2). ${ }^{39}$

Republican soldiers were rarely interred with any identification and were often recorded as 'Unknown' in the book in which were inscribed the details of those interred in the crypts of the Valley of the Fallen, despite the fact that there was definite information concerning the town from which the wooden caskets containing their remains had come.

In 1959, 11,329 sets of remains were interred (or reinterred) in the Valley of the Fallen, followed by a further 2,502 in 1960 and 6,608 in 1961. Remains continued to be interred there every year until 1983, when the final interment was recorded in the register that was kept by the Benedictine monks and that now belongs to National Heritage. Although it is impossible to give an exact figure because of the circumstances surrounding the opening of the graves in the 1960s and the way in which the remains were exhumed, in 2011 National Heritage established that in total 33,847 bodies were interred in the crypts. This calculation was made at the request of the Commission of Experts on the Future of the Valley of the Fallen, ${ }^{40}$ which was created in the same year.

In theory, families were supposed to receive a document after the process of reinterment that certified the crypt and columbarium in which the remains of their loved ones were finally laid to rest. However, these documents have been found in many civil government and local council archives, ${ }^{41}$ meaning that it is difficult to establish to what extent those who could have been informed did in fact receive the information.

\section{A new Escorial}

Let us now look in greater detail at the geographical location of the monument and its technical characteristics. The Valley of the Fallen is sited very close to another large monument that is important in the establishment and configuration of Spanish identity, namely the Royal Monastery of San Lorenzo de El Escorial, which was built in the sixteenth century by Philip II and is where the kings and queens of Spain have been buried since that time. The Valley of the Fallen is nine kilometres from El Escorial (at present twelve minutes by car) and on a higher slope (El Escorial being at an altitude of 1,028 metres and the Valley of the Fallen at 1,758 metres). It also occupies a larger area of land $\left(33,327 \mathrm{~m}^{2}\right.$ for El Escorial, but 1,377 hectares for the Valley of the Fallen). The two monuments feature the same elements (although the latter has a few additional ones): a monastery, a basilica, a library and a youth centre, with the desire to make a lake in the form of a cross at Cuelgamuros never having been fulfilled. If we also look at the detailed numbers concerning volumes and surface areas, we can see that in every respect the Valley of the Fallen surpasses El Escorial. ${ }^{42}$ The most remarkable, visual and significant example of this is the great cross that rises above the Francoist monument, which is 150 metres high and visible from a distance of forty kilometres. These details alone bear witness to a desire to surpass what had been built previously. 
Table 1 Number of individuals whose remains were interred in the Valley of the Fallen and year of interment

\begin{tabular}{lc}
\hline Year & Number of interments \\
\hline 1959 & 11,329 \\
1960 & 2,502 \\
1961 & 6,608 \\
1962 & 1,115 \\
1963 & 1,656 \\
1964 & 2,904 \\
1965 & 895 \\
1966 & 1,467 \\
1967 & 97 \\
1968 & 2,919 \\
1969 & 648 \\
1970 & 87 \\
1971 & 1,222 \\
1972 & 23 \\
1973 & 56 \\
1974 & 10 \\
1975 & 3 \\
1977 & 1 \\
1981 & 304 \\
1983 & 1 \\
\hline
\end{tabular}

Was Franco attempting to rival and outdo the royal pantheon? From the perspective of its construction, it is obvious that even if this was not the intention (no document has yet been found in which this aim is explicitly expressed), he did indeed achieve it. Not only was El Escorial a source of inspiration, as Fernando Olmeda claims, ${ }^{43}$ but in this regard there was also a wish to surpass it. But what about at a symbolic level?

Although there was a later (frustrated) attempt by the regime to change the status of the monument ${ }^{44}$ in the early years it was clear for whom the crypts were to be. The decree initiating the construction of the Valley of the Fallen is explicit, specifying that the monument will be where there shall be raised a grand temple to our dead in which for centuries to come prayers will be said for those who fell for God and the nation; a permanent place of pilgrimage where the greatness of nature will bestow dignity upon the field in which the heroes and martyrs of the Crusade are laid to rest. ${ }^{45}$

Likewise, on the day when the construction of the new temple began in $1940 \mathrm{a}$ mass was said, and 'at the end of the religious ceremony the priest himself prayed out loud an oration for all the martyrs and those fallen for the nation' ${ }^{46}$ Republican soldiers and civilians were never considered as 'martyrs and fallen'. In 1942 they were still talking very explicitly about the remains that were to be laid to rest in the 
crypts of Cuelgamuros: 'News has also been announced of the great national monument to the heroes of our war of liberation, which on the initiative of El Caudillo is to be erected in the Valley of the Fallen, near the Monastery of El Escorial. ${ }^{37}$ And the monument was thought of in a similar vein in 1952, when internal and external political circumstances had already begun to change substantially, the most significant development being the reopening of foreign embassies in Spain in 1950. Spain was beginning to emerge from isolationism, but the Valley of the Fallen continued to be for certain people only.

In that year, in a lengthy article published in La Vanguardia Española, one of the main state newspapers, on 20 November (the date when José Antonio Primo de Rivera was executed) the state of the works was presented and even a plea was made to the mothers of those who had died during the war - although only to the mothers of the victors:

To the left and right are the galleries for the interments. We wish here to ask all mothers to take their mourning to this immortal place. There is only one thing to consider. In any other cemetery, after three generations all trace of heroic prowess will have disappeared, whereas in the Valley of the Fallen those who died on the field of battle or in any summary execution will deservingly have their memory perpetuated forever. ${ }^{48}$

A new pantheon was being built. It was greater than that of San Lorenzo de El Escorial and was for a new dynasty born of the blood of the fallen, its cement being the remains of the heroes and martyrs who had died defending a new, Francoist Spain. The Valley of the Fallen had to be the greatest temple of the new political religion, which was based on a new vision of the world in which, 'if José Antonio was the Prophet, El Caudillo is the Messiah, the incarnation of God and the Fatherland, the supreme priest of the religion of state accompanied by the Holy Spirit of Hispanidad'. ${ }^{49}$

From the very beginning of the works, the press had begun to make comparisons between the two monuments. La Vanguardia Española recorded 'the symbolic inauguration of the grand monument that will immortalise the memory of the fallen'. It explained that 'the place chosen is at a higher altitude than the site of the monastery of San Lorenzo'. ${ }^{50}$ The monument was an 'admirable work that will immortalise El Caudillo', ${ }^{51}$ in the words of the President of the Philippines following a visit to the works at Cuelgamuros in 1951. Visiting the Valley of the Fallen became obligatory for all foreign representatives who began to visit Spain in an official capacity, both while the works were progressing and once the finished project had been inaugurated. The visit, an interview with the dignitary, the tour itself and photos of activities: everything was fully recorded by the newspapers for both the broadest and the most politicised audiences. What better way to introduce the new monument to society than through the visits of foreigners who marvelled at its size and grandeur?

The usual tour involved visiting the monastery at El Escorial and then the works at Cuelgamuros, with more time spent at the latter. The newspapers of the time ${ }^{52}$ 
always reported on this tour, which by 1959 had been undertaken by the minister of foreign affairs of Peru, Manuel Gallagher (October 1951); the president of Portugal, Craveiro Lopes (May 1953); Rafael Leónidas Trujillo, the Dominican dictator (June 1954); the Greek field marshal Alexandros Papagos (October 1954); the shah of Persia (May 1957); and the Egyptian minister of foreign affairs (November 1957).

The reactions of these visitors of the 1950s were always admiration for the way in which the whole site was taking shape, but the visit that best expressed Franco's pretensions was that of the minister of foreign affairs of Peru, Manuel Gallagher, who stated that 'the Valley of the Fallen, not only by its construction, but also by the significance of its location next to the monastery of El Escorial, is a demonstration that Spain is rising once more victorious' ${ }^{53}$ On 20 November 1952, in the same article quoted above, ${ }^{54}$ there was further explanation of these pretensions, and a mystical and supernatural aura was bestowed upon the dictator for having thought up the whole concept and chosen the site when the war had only just ended:

Only one question can express the concerns and perplexity of the visiting journalist: 'Is it better than El Escorial?' No, in fact it is something different. Philip II ordered his men to build a monument to commemorate victory that was, given the meagre resources available, a master work, a human work. Franco, who was already thinking about paying tribute to the heroes and martyrs while the Spanish Civil War was still in progress, at the end of a day of walking found the site and said to the heroic Moscardó, 'This is the place.'

The Valley of the Fallen was the new monument for the new Spain, and it was necessary to give it an air of transcendental mysticism. The best cement and foundation for such a perception in the future were the remains of those who had died in the civil war. The cult of death is more than evident; the monument concentrates what Francisco Sevillano has described as a 'culture of war' that would include three different sections, united one to the other by the idea of the nation: the image of the enemy, the exaltation of the God-given 'Caudillo' and the cult of the 'fallen', which operated in a binary manner by opposing good and evil, the sacred and the profane, in the struggle for the redemption of Spain. ${ }^{55}$

An October 1959 feature that reported that the task of transferring remains from Barcelona to the crypts at Cuelgamuros was almost complete stated:

May we stress how those who died for Spain, for the Spain of the future, will find in her entrails, in the rocks of that place known as the Valley of the Fallen, the best company for their mortal remains. The new Spain wished to offer them this major work, this distinguished final resting place, as a gift from those who now live looking to tomorrow, yet rooted in a past that saw unforgettable sacrifices. ${ }^{56}$

As the works advanced and a possible date for inauguration grew closer, one can increasingly see the desire for the Valley of the Fallen to at least equal San Lorenzo de El Escorial. The newspaper Imperio published an article on 17 July 1957 with 


\section{Queralt Solé}

the long title 'The Valley of the Fallen will commemorate Spanish history and heroism for ever. A monument for the contemplation of the centuries to come. A new Escorial for fervent pilgrimage.' The article added nothing to what was already known about the monument, but besides the explicit title, the first lines of the text were very clear in respect of the intentions behind the new monument:

The twentieth century in Spain has found its new version of El Escorial. This, like the previous one, lies some fifty or sixty kilometres from the capital of the nation, and already proclaims, with its recently perfected physical nature, that it will be able to attract the admiration and enthusiasm of those who come after us. ${ }^{57}$

Imperio was a mouthpiece for Falangism, the ideological doctrine that Francoism officially adopted, so it is not surprising that it promoted the Valley of the Fallen as the 'New Escorial', nor should it be surprising that it raised it up as a place of pilgrimage for a new race, making explicit the fascist vision of its political religion:

Exaltation in stone, in wood, in painting and metal, of the character and sanctity of the race, from the moment of the race's consciousness of its own national being. That is all. The centuries to come will be able to weigh up the huge undertaking that is about to be inaugurated better than we can. ${ }^{58}$

The Falangists most vehemently put forward the claim that the Valley of the Fallen should be a new Escorial as a place of interment for those who had lost their lives for the 'New Spain'. This makes sense when one considers that the cult of the martyrs and the fallen was the first ritual expression of the Falangist aesthetic. ${ }^{59}$ On 4 October 1958 a clearly Falangist lawyer from Barcelona, Juan Vidal Salvó, ${ }^{60}$ published an editorial comparing Franco to Philip II and highlighting the qualities of the former to those of the latter:

But the Generalísimo, who never gave in to obstacles, as his life as a fighter exemplifies, did not follow the path of the prudent King Philip II in order to overcome bureaucratic problems. When Philip II decided to build the monastery of El Escorial, he charged a commission of technicians with looking for a site for such a transcendental undertaking. But Franco personally tackled the problem, and one day in 1938, in the middle of our War of Liberation, travelling with a reduced entourage, which included the hero of the Alcázar de Toledo, Lieutenant General Moscardó, in the vast lands of Cuelgamuros, imposing in its mountainous ferocity, he found what he had been seeking with such great effort. There would be built the monument intended to perpetuate the memory of the Fallen of the Crusade. ${ }^{61}$

Notice that, as in 1952, Franco is the one who has a vision, alongside the heroic Moscardó, of the place where the Valley of the Fallen should be built. This theme was to be repeated in the various reports focused on the monument. There was a desire to transform Cuelgamuros into a mystical place, thanks to its location close to El Escorial, to its omnipresence and to the human remains transferred to it. The 
poet Lope Mateo ${ }^{62}$ wished to contribute to giving transcendence to the monument and wrote in October 1958:

The sound of your bells carries us out of time, beyond time, where God resides. In you, Cuelgamuros, we see a Spain that is transcended, ascendant, perplexed by an infinity that leaves here the great ossuary of its children to move forward with its own history, crying out for the winds of the future. And what else could Spain do, but offer its time, its time of heroism and mourning to perpetuate it into eternity?

Just one day before the inauguration of the whole complex, on 31 March 1959, the remains of José Antonio Primo de Rivera, the founder of the Spanish Falange, were brought from El Escorial. He had been executed in November 1936 in Alicante, where he had initially been buried. At the end of the war his remains had been transferred to El Escorial, an event that lasted ten days and saw the involvement of a great number of lay people and the conversion of José Antonio into the undoubted martyr of the dictatorship, as Zira Box ${ }^{63}$ has analysed in depth. It was another temporary interment, as in 1959 the remains of José Antonio was transferred once more, this time to what was to become the pantheon of the new Spain, the Valley of the Fallen. On this occasion there was again a great showpiece of an event, with the coffin borne on the shoulders of bearers right up to the new basilica, where José Antonio was interred behind the great altar. The 1959 ceremony was not as opulent as that of 1939, and Franco did not attend, nor did he receive the coffin at Cuelgamuros. Nevertheless, the intention was clearly to establish the new place of pilgrimage for the new Spain based on the remains deposited in the crypts of the Valley. And it could not be without those of the figure who had been turned into the first of the fallen and a martyr: José Antonio Primo de Rivera, founder of the Spanish Falange.

Spanish kings and princes were interred at El Escorial, but the monument of the new Francoist Spain, the Valley of the Fallen, would be the eternal resting place of the human remains of the representatives of a new dynasty - perhaps not one of blood, but certainly one of ideology and unity in victory. The original idea was that those who had died defending their country and religion would be interred there, with the last to be interred being the dictator himself.

\section{Notes}

1 J. Rodrigo, Hasta la raíz: Violencia durante la Guerra Civil y la dictadura franquista (Madrid, Alianza, 2008).

2 J. Cuesta, La Odisea de la memoria. Historia de la memoria en España. Siglo XX (Madrid, Alianza Editorial, 2008).

3 Founder of the Juntas de Ofensiva Nacional Sindicalista (JONS), a political party close to fascism that merged in 1934 with Falange Española, the fascist party founded by José Antonio Primo de Rivera. He died during the civil war.

4 A Spanish soldier who led the failed coup d'état on 18 July 1936 that led to the Spanish Civil War. He died during the civil war in an air accident, at the spot where the monument was erected. 


\section{Queralt Solé}

5 The one published in 1983, which went into three editions, was an update of a previous book which had been published in 1977 under the same title (Madrid, Ed. Sedmay) but which had not had much impact. The author died in 1986, and the publishing house La Esfera de los Libros republished the book in 2006.

6 F. Olmeda, El Valle de los Caídos. Una memoria de España (Barcelona, Península, 2009).

7 Razones por las que se construyó la basílica del Valle de los Caídos (Reasons Why the Basilica of the Valley of the Fallen Was Built) (Madrid, Fundación Francisco Franco, 1976).

8 J. Blanco, El Valle de los Caídos. Ni presos políticos ni trabajos forzados (Madrid, Fuerza Nueva, 2009).

9 Q. Solé, Els morts clandestins: Les fosses comunes de la Guerra Civil a Catalunya (1936-1939) (Barcelona, Editorial Afers, 2008); Q. Solé, 'El secreto del Valle: Los nombres de los miles de muertos trasladados por Franco desde las fosas catalanas', Sapiens, 67 (2008), 15-20; Q. Solé, 'Inhumados en el Valle de los Caídos: Los primeros traslados desde la provincia de Madrid', Hispania Nova, 9 (2009), 220-49, http://hispanianova.rediris.es (accessed 25 January 2016).

10 A. Bárcena, 'Redención de penas en el Valle de los Caídos: las fuentes rebaten el mito', Aportes, 79:2 (2012), 5-29.

11 B. Moreno Garrido and J. C. Rueda Laffond, 'Televisión y Memorias sobre la Violencia', Hispania Nova, 10 (2012), 659-80, http://hispanianova.rediris.es (accessed 10 January 2016).

12 Cuesta, La Odisea de la memoria.

13 Z. Box, 'La Fundación de un régimen. La Construcción simbólica del franquismo', doctoral thesis, Universidad Complutense de Madrid, 2008, http://eprints.ucm. es/8572/1/T30783.pdf (accessed 25 January 2016).

14 P. Aguilar, 'Los Lugares de la memoria de la guerra civil. El Valle de los Caídos: la ambigüedad calculada', in J. Tusell (ed.), El Régimen de Franco, 1936-1975: política y relaciones exteriors, 485-498 (Madrid, UNED, 1993).

15 Ibid.

16 K. Hite, Política y arte de la conmemoración. Memoriales en América Latina y España (Santiago de Chile, Mandrágora, 2013).

17 Translator's note: All quotations from Hite, Política y arte de la conmemoración have been back-translated from the Spanish-language version of the work.

18 L. Castro, Héroes y caídos: Políticas de la memoria en la España contemporánea. (Madrid, Catarata, 2008).

19 M. Albert-Llorca, 'Les Avatars de la mémoire des morts de la guerre civile espagnole (1936-1939) et le mausolée du Valle de los Caídos', in A. Bouchy and M. Ikesawa (eds), La Mort collective et le politique: Constructions mémorielles et ritualisations (Tokyo, Institut des sciences humaines et sociales, Université de Tokio, 2011).

20 F. Ferrandiz, El Pasado bajo tierra. Exhumaciones contemporáneas de la Guerra Civil (Barcelona, Anthropos, 2014).

21 A. González-Ruibal, 'Topography of Terror or Cultural Heritage? The Monuments of Franco's Spain', in N. Forbes, R. Page and G. Pérez (eds), Europe's Deadly 
Century: Perspectives on 20th Century Conflict Heritage (London, English Heritage, 2009), pp. 65-72.

22 NO-DO, the initials of Noticiarios y Documentales Cinematográficos (Cinema News and Documentaries), http://www.rtve.es/filmoteca/no-do/not-848/1487547/ (accessed December 2014).

23 Moreno and Rueda, 'Televisión y Memorias sobre la Violencia', 29.

24 The majority of the films and documentaries mentioned can easily be found on the internet.

25 F. Ferrándiz, 'Guerras sin fin. Guía para descifrar el Valle de los Caídos en la España contemporánea', Política y Sociedad, 48:3 (2001), 481-500; F. Ferrándiz, El Pasado bajo tierra. Exhumaciones contemporáneas de la Guerra Civil (Barcelona, Anthropos, 2014).

26 Boletín Oficial del Estado, 2 April 1940, 2240.

27 Ibid.

28 Hite, Política y arte de la conmemoración, p. 38.

29 The relationship between religion and the army in the Spanish state has always been very close, to the point where on 1 October 2012 the minister of the interior, Jorge Fernández Díaz (Partido Popular), awarded the Great Cross of the Order of Merit of the Guardia Civil (a militarised body in Spain) to the Virgin del Pilar, who is the patron of that body. See the order published in the Boletin Oficial del Estado at https://www.boe.es/diario_boe/txt.php?id=BOE-A-2012-12277 (accessed December 2014). The different patron saints of the Spanish armed forces and of the Guardia Civil can be found at http://www.portalcultura.mde.es/actividades/ aniversarios/Conmemoraciones/Patronos_Patronas/ (accessed December 2015).

30 Explained in detail on the website www.valledeloscaidos.es (accessed November 2014).

31 G. Di Febo, Ritos de guerra y de victoria en la España franquista (Bilbao, Desclée de Brouwer, 2002).

32 S. Nonell Bru, Así eran nuestros muertos (Barcelona, Casulleras, 1966).

33 Olmeda, El Valle de los Caídos, pp. 194-9; Solé, Els morts clandestins, pp. 120-4.

34 Provincial Archives of Lérida, Lérida, Civil Government Collection, Transfer of remains to the Valley of the Fallen, municipal district of La Sentiu de Sió.

35 D. Sueiro, El Valle de los Caídos. Los secretos de la cripta franquista (Barcelona, Argos Vergara, 1983), p. 208; Solé, Els morts clandestins, p. 152.

36 General Archives of the Administration, Alcalá de Henares (hereafter AGA), Interior Collection, file 44.

37 Ibid.

38 Solé, 'Inhumados en el Valle de los Caídos'.

39 F. Etxeberria and K. Pla, El Cementerio de las botellas. El Fuerte de San Cristóbal en la memoria: de prisión a sanatorio penitenciario (Pamplona: Aranzadi/Pamiela/ Txinparta, 2014), p. 117.

40 Report by the Commission of Experts on the Future of the Valley of the Fallen. Delivered to the Ministry of the Presidency in Madrid, 29 November 2011, p. 11, http://www.memoriahistorica.gob.es/NR/rdonlyres/0F532FC5-FE23-4B8D- 


\section{Queralt Solé}

AA3A-06ED4BFAFC49/184261/InformeComisinExpertosValleCados.pdf (accessed February 2015).

41 Solé, Els morts clandestins; J. Díaz Arriaza (ed.), Un rojo amanecer (Seville, Patronato del Real Alcázar, 2011).

42 See the website of Patrimonio Nacional (National Heritage), which now manages both monuments: http://www.patrimonionacional.es/real-sitio (accessed 25 January 2016).

43 Olmeda, El Valle de los Caídos.

44 P. Aguilar, Memoria y olvido de la Guerra Civil española (Madrid, Alianza Editorial, 1996).

45 Boletín Oficial del Estado, 2 April 1940, 2240.

46 'El Caudillo preside la inauguración simbólica del grandioso monumento que inmortalizará la memoria de los Caídos', La Vanguardia Española, 2 April 1940, p. 2.

47 'El Caudillo preside la inauguración de las Exposiciones de Arquitectura Alemana Moderna y de Trabajo de Arquitectura Española', La Vanguardia Española, 7 May 1942, p. 1.

48 'La construcción del monumento nacional en el "Valle de los Caídos"', $L a$ Vanguardia Española, 20 November 1952, p. 4.

49 L. Zenobi, La Construcción del mito de Franco (Madrid, Cátedra, 2011), p. 332.

50 'El Caudillo preside la inauguración simbólica del grandioso monumento que inmortalizará la memoria de los Caídos', La Vanguardia Española, 2 April 1940, p. 2.

51 'La estancia del presidente de Filipinas en España', La Vanguardia Española, 7 October 1951, p. 1.

52 'La estància del presidente Quirino en Madrid', La Vanguardia Española, 6 October 1951, p. 1; 'Manifestaciones del ministro de Asuntos exteriores en Perú a los periodistas', 12 October 1951, La Vanguardia Española, p. 1; 'La estancia del Presidente de Portugal en España: La visita al Monumento nacional a los Caídos', La Vanguardia Española, p. 1; 'El Caudillo y el presidente portuguès visitaron El Escorial y el Monumento a los Caídos', Hoja del Lunes, 18 May 1953; 'Franco y Trujillo visitan El Escorial. Oraron ante la tumba de José Antonio. También estuvieron en El Valle de los Caídos', Imperio: Diario de Zamora, 10 June 1954, p. 1; 'En compañía de S. E. el Jefe del Estado, el Sha realizó ayer una detenida visita al Museo del Prado. Por la tarde, y también acompañado por el Caudillo, visito El Escorial y el Valle de los Caídos', La Vanguardia Española, 25 May 1957, p. 1.

53 'Manifestaciones del ministro de Asuntos exteriores en Perú a los periodistas', $\mathrm{La}$ Vanguardia Española, 12 October 1951, p. 1.

54 'La construcción del monumento nacional en el "Valle de los Caídos"', $L a$ Vanguardia Española, 20 November 1952, p. 4.

55 F. Sevillano Calero, 'La Propaganda y la construcción de la cultura de guerra en España durante la guerra civil', Studia historica: Historia contemporània, 32 (2014), 225-37.

56 'El traslado de varios caídos al Valle de Cuelgamuros', La Vanguardia Española, 12 March 1959, p. 21. 
57 A. Antúnez, 'El Valle de los Caídos perpetuará la historia y el heroísmo hispanos', Imperio: Diario de Zamora, 17 July 1957, p. 6.

58 Antúnez, 'El Valle de los Caídos perpetuará la historia y el heroísmo hispanos'.

59 Sevillano, 'La Propaganda y la construcción'.

60 Catalan Falangist (1897-1974), lawyer and writer, who is believed to have been the first head of the Falange in Barcelona in 1933.

61 'Franco y el Valle de los Caídos', La Vanguardia Española, 4 October 1958, p. 4.

62 Journalist and poet (1898-1970), who won numerous prizes as a poet and worked on various Spanish newspapers.

63 Box, 'La Fundación de un régimen'. 